This is a self-archived version of an original article. This version may differ from the original in pagination and typographic details.

Author(s): Palonen, Kari

Title: Parliamentary and Electoral Decisions as Political Acts

Year: 2019

Version: Accepted version (Final draft)

Copyright: @ Daniel Bessner \& Nicolas Guilhot, 2019.

Rights: In Copyright

Rights url: http://rightsstatements.org/page/lnC/1.0/?language=en

Please cite the original version:

Palonen, K. (2019). Parliamentary and Electoral Decisions as Political Acts. In D. Bessner, \& N. Guilhot (Eds.), The Decisionist Imagination : Sovereignty, Social Science and Democracy in the 20th Century (pp. 85-108). Berghahn Books. 


\section{Parliamentary and Electoral Decisions as Political Acts}

Kari Palonen, University of Jyväskylä

To speak of 'decisions' has two different connotations in studies of political thought. The first one is that of closing an open situation by an irrevocable final decision, a fait accompli that forever alters the conditions of political action. Carl Schmitt's Politische Theologiei provides a paradigm for it. It is, however, equally possible to insist on the necessity of a choice in combination with the contingency of the decision, and the absence of sufficient grounds for the choice then marks the freedom of political action.ii

Even if these two aspects may in some respects be two sides of the same coin, their political context is highly different. In the first case a dramatic and extraordinary decision is committed by an authorized instance; in the second case the decisions can be frequent and multiple, and they are available to a great number of political agents. In the first setting the question is whether the decision is necessary or even possible at all; in the second perspective contingent decisions are treated as a regular part of parliamentary and democratic polities.

In this essay I want to discuss the character and political quality of parliamentary and electoral decisions. My point of departure is Max Weber's booklet Wahlrecht

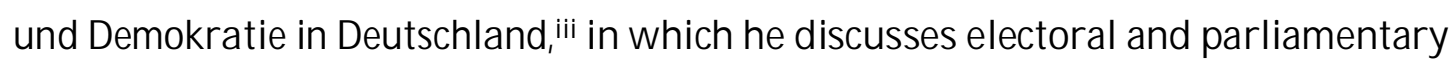
politics in the context of the acceptance of the democratization of suffrage. I shall, however, complement the analysis with the procedural literature around the Westminster Parliament in order to illustrate the multistage and multilayer character of parliamentary decisions and their close links to the preceding debates on the items on the parliamentary agenda. ${ }^{\text {iv }}$

The combination of debate and decision by voting is one of the original features that make the Westminster Parliament a close approximation of the parliamentary ideal type of politics. Gilbert Campion, a twentieth-century Clerk of the House of Commons, formulates the point thus: "Motion, Question and Decision are all parts of a process that may be called the elementary form of debate".. 
What Campion writes about 'debate' is a remarkable extension of the concept as marking the singularity of the parliamentary style of politics. Parliamentary debate is the opposite of a polite conversation to reach a consensus, but neither does it simply repeat already existing stands of the government and opposition. In parliament, opposite standpoints alternate and the dissensus between perspectives enriches the understanding of the question on the agenda. The Canadian rhetoric scholar James De Mille put it as follows: "The aim of parliamentary debate is to investigate the subject from many points of view which are presented from two contrary sides. In no other way can a subject be so exhaustively considered."vi Here we can see a kind of methodological justification of debate as political action: a question can be properly understood if and only if it is approached from opposite points of view. Parliamentary procedure and rhetoric are forms of thinking politically. From this perspective neither the authority of the best argument nor the decisionistic separation of vote from debate appear plausible.

Decisions versus 'the best argument'

Before discussion on the relationship between debate and vote in parliamentary and electoral contexts, a few words are needed on the broader context of debate, namely on the dualism between the ultrarationalistic and the decisionistic tradition. Ultrarationalists from Hegel to Habermas regard making a decision per se as something suspicious. They are instead looking for the 'best argument' in a discussion, as something 'inexpugnable' (to quote Thomas Hobbes's term vii), something that silences the audience.

This setting is based on the assumption that everyone has recognized a priori the "unforced force of the best argument", as Habermas's favorite phrase goes. In an early formulation Habermas connect this with the idea of emancipation to adulthood (Mündigkeit) as the given structure of the human language. With is "the intention of a general and unforced consensus unmistakable formulated", translations without reference are my own. viii 
Against Weber and others, Habermas once formulated his point of criticism as follows: "In the last resort political action cannot be justified rationally, but rather take place by a decision between competing orders of values and powers of belief, which escape compelling arguments and remain inaccessible to a binding discussion".ix In other words, he accused them of replacing 'rationally justified' political action by a decision between 'competing orders of values and beliefs', which would be inaccessible to the force of argument and to a 'binding discussion' allowing the participants to arrive at a consensus.

When such a 'force' is presupposed, there is no need either to ascribe decisionmaking to an entity or to a person or to recourse to a vote. Such a setting of the question is highly partisan. Behind it is, and this is also explicit in the view of Mündigkeit as a given structure of language, obviously the classical contractarian paradigm of a transition from the 'state of nature' to the 'state of civilization' or 'state of society'. This move is formally voluntary, but still does not constitute a genuine decision, because staying in the state of nature is not a serious alternative. Only within this paradigm could 'discussion' lead to a 'binding' solution as a quasilogical move accepted by all. In other situations, however, what counts as an 'argument' and what should be the criteria of the 'best argument' can be seen as controversial in principle, and subject to change as well, due to new moves in the 'discussion'.

From the existentialist or Weberian tradition the possibility of making political decision will be seen an expression of human freedom of choice. Following his critical evaluation of the entire Frankfurt school's inability to deal with politics ${ }^{\mathrm{x}}$, my late colleague Michael Th. Greven sketched a "democratic decisionism" in a series of articles from 1990 onwards, collected to his book Kontingenz und Dezision and in his monograph Die politische Gesellschaft, ${ }^{x}$. He insisted both on the necessity and the importance of decisions in democratic and parliamentary politics and on removing the authoritarian tone from the concept of decisionism. Similarly to such 'existentialist' authors as Karl Jaspers and Jean-Paul Sartre, xii Greven strongly insists on a close connection between decision and responsibility, with a special emphasis 
on its political significance xiii From an different angle, rhetorical tradition, for its part, sees that in politics there is always the possibility to argue in utramque part, and therefore the choice is left to the political agents themselves .iv $^{\text {xiv }}$

The Habermasian ideal of a consensus also gives the impression of a religious conversion: the ideal discussion appears as if it would convert the last 'pagan' participant and draw her into the community of believers. John Stuart Mill offers a rhetoric-inspired counter-position for this conversion-by-consensus in On Liberty:

\begin{abstract}
If all mankind minus one, were of one opinion, and only one person were of the contrary opinion, mankind would be no more justified in silencing that one person, than he, if he had the power, would be justified in silencing mankind.... But the peculiar evil of silencing the expression of an opinion is, that it is robbing the human race; posterity as well as the existing generation; those who dissent from the opinion, still more than those who hold it. If the opinion is right, they are deprived of the opportunity of exchanging error for truth: if wrong, they lose, what is almost as great a benefit, the clearer perception and livelier impression of truth, produced by its collision with error. ${ }^{\mathrm{xv}}$
\end{abstract}

For Mill, not only the arguments and the criteria for judging their goodness are contested. The very ideal of consensus is nothing worth striving for. In matters of opinion, no binding decisions are needed, for dissensus has a value of its own. However, political matters are not merely questions of opinion, but also struggles for power that are incompatible with each other. Mill, of course, undertook to change the existing power relationships when he was a member of the House of Commons. In the 1867 debate on parliamentary suffrage he moved his famous amendment for female suffrage by replacing the word "man" with "person".xvi

Besides the ultrarationalists, an intellectual current opposed to them, the German romantic tradition of the early nineteenth century, also failed to recognize the political necessity of decisions. Carl Schmitt's published Politische Romantik (1919), before his better known works Die Diktatur (1921) and Politische Theologie (1922), and identified the counter-position to his own thinking, in German romanticism. For Schmitt romanticism was not merely a philosophical or literature current, but also a militantly anti-political style of thought, even if the romantics might have thought 
otherwise. Schmitt famously blamed the German romantic conservative Adam Müller indulging in an "eternal conversation", ewiges Gesprächxvii.

Indeed, if Habermas wants to avoid an unending moment of conversation, looking for the best argument without any limits is liable to lead precisely there. Political action takes place in time and operates with time, and the scarcity of time makes decisions necessary. Søren Kierkegaard's point against Hegel's self-development of reason in history was exactly the idea that sooner or later we are faced with the necessity of making a decision, choosing either one side or the other (enten-eller). For Kierkegaard the theologian, the choice was for or against God. xviii

Schmitt, the Catholic jurist, was indebted to the Lutheran Kierkegaard. His paradigm is the pure and absolute decision, created ex nihilo, "a pure, non-justified, non-reasoned, undiscussed, illegitimate decision, thus one created out of nothing" xix The sovereign dictator is the instance of the making of this decision, as formulated in the first words of Schmitt's Politische Theologie on the decision to declare a state of exception. "The sovereign is one who decides on the state of exception".xx

Contrary to both Hegel and the Romantics, Kierkegaard and Schmitt had excellent grounds to affirm that decisions are necessary in a polity. No decision arrives by itself, as a result of a consensual conversation. The appeal for the consensus is, rather, a rhetorical justification for silencing adversaries or prolonging the discussion ad infinitum. Both Kierkegaard and Schmitt refer to limit situations, in which decisions are unique, dramatic and irreversible. Yet, such situations do not help much in understanding other kinds of politically important decisions, such as voting in Parliament and in elections.

Decisions by vote

The paradigmatic form of political decision-making in democratic and parliamentary practice is the vote. The German terms Abstimmung and Wahl both refer to decisions by a counting of votes. The former concerns an item on the agenda in a Parliament or a meeting, the second a choice made by a person.

Weber makes the important distinction between election and acclamation. A 
referendum is an example of acclamation. "A plebiscite is not an election but a onetime or ... repeated recognition of the position of a pretender as a personally qualified charismatic ruler". ${ }^{\text {xxi }}$ Following the rules of epideictic rhetoric, the voters in a referendum or a plebiscite have only the choice between a given yes and no, between acclaiming or refusing to do so. The second round of the presidential election in the French and Finnish system resembles a referendum, although a yes for one candidate marks a no for the other. Voting blank, that is, against both, might make more sense in such an election than in a referendum. For Schmitt acclamation is the only way for 'the people' to act politically, and he supports both referenda and presidential regimes. ${ }^{\text {xii }}$

For Weber it is possible to transform acclamation into a genuine election by regularization, whatever the final exact method of the election. "The acclamation by the ruled can ... also develop into a regular 'election procedure', including by norms of regulated direct or indirect 'suffrage, with local or regional elections, classes of voters and electoral districts'. "’xxiii A regularization of the electoral system increases both the contingency of the choice between alternatives and the fairness of the electoral procedure. Fair elections are opposed to governmental support for the 'yes' side in a referendum and to a 'no' side that turns into a plebiscite against the government. Weber sees a transformation from acclamation to election to be present both in the US with its semi-direct presidential elections and in the British-type parliamentary representation. "Only in the occident has the election of rulers step by step developed into a representative system". xxiv

In the older electoral systems the number of votes and voters is by no means always the same. On the contrary, the votes of different voters might have a different weight, based on varying grounds. In contrast, counting votes is a major aspect in the democratization of a polity or an institution. This political transition is the main topic of Weber's Wahlrecht booklet, published during WWI late in 1917. At this stage the transition to parliamentary government was already on the agenda of German parliamentary and public debate, while in opposition to it various antidemocratic and anti-parliamentary modes of thinking were militantly advocated by war hawks. 
Weber's targets of criticism include plural voting, as practiced at his time in Belgian parliamentary elections, and what he called the "plutocratic" tripartite division of the electorate in the elections of the Prussian lower house. Both cases operated with maleonly suffrage and the votes were counted and not weighted. However, in Belgium extra votes on the basis of certain criteria (family, degrees, property, etc.) were given to some voters, while in Prussia the electorate was divided into three classes on the basis of taxation, and votes had varying weights in deciding the composition of the parliament. A partisan distribution of parliamentary seats in favor of the old order was predetermined, although the exact distribution of votes was not.

In such elections a lesser importance is attached to voter choice than in equal suffrage, in which a radically contingent distribution of votes is the ideal. Weber regards both types of unequal elections as expressions of the cowardice of the bourgeoisie in the face of democracy ${ }^{\mathrm{xxv}}$, of its unwillingness to acknowledge democratic equality and the political contingency of electoral results.

For Weber suffrage by numbers (Ziffernwahlrecht) is, furthermore, an indispensable part of the 'mechanical nature of the modern state'. The independence of citizens (Staatsbürger) is manifested in equal suffrage, in which all citizens are treated equally as political agents, as opposed to the plural voting and the tripartite division of voters in the Prussian Abgeordnetenhaus. "The modern state is the first to have the concept of the citizen of the state (Staatsbürger). Equal voting rights mean in the first instance simply this: at this point in social life the individual, is not, as everywhere else, considered in terms of a particular professional or family position, nor in terms of differences in material or social station, but purely and simply as a citizen." xxvi Equality of suffrage has for Weber an 'anthropological' justification in the equality of citizens before the state, whose representatives do have power over life and death.

The 'one person, one vote' principle as well as the equal weight of votes in both general elections mark for Weber a decisive break with the regimes of the estates of the realm. A political consequence of this break was the profound contingency it brought to the voting. Even if parties try to bind voters to their own viewpoints, the procedure of elections and intra-parliamentary votes ensures that the votes are 
counted one by one. The decisions of voters are singular acts that result in contingent numerical constellations in elections, out of which parliamentary majorities will be formed and revised through debates and intra-parliamentary votes.xxvii In this sense parliamentary and electoral votes are far from the existential decisions before God à la Kierkegaard, the groundless decisions of the Schmittian "sovereign" and the 'non-decisions' based on best argument' à la Habermas.

The second and even more important target of Weber's polemics is the call of numerous literati in war-time Germany to replace universal and equal suffrage with a corporative representation, berufsständische Vertretung. The point of such proposals is to replace decision by vote with diplomatic-style negotiations between professional corporations.

For Weber such principle corresponds to the feudal system of estate representation. The division of persons according to specific interests or occupations was to some degree possible in a regime of separate estates. In the estate assemblies there was neither a vote nor a binding decision, but a complex of compromises serving as the juridical basis for decisions. "Only when compromise was the legal basis of political action did the estate structure based on occupation inherently have a proper place."xxviii

For example, in the four-estate Swedish Riksdag - which persisted until 1866, and in Finland (as part of the Russian empire) until 1906 - the final decision was found in the negotiations between the estates' representatives. Even if the Peasants and the Burghers represented a much broader section of the population, their weight was similar or lesser to that of the 'higher estates' of the Nobility and the Clergy. In some cases a majority of three estates was sufficient to put through a motion, in others an agreement between the four estates was necessary. Although the imperative mandate for members within the estates was rejected in the Swedish 1810 Constitution (Instrument of Government) and in the Finnish 1869 Diet's procedure, ${ }^{x x i x}$ compromise between estates persisted as the basis for decisionmaking in the Diet. Without an agreement between estates, no decision was possible.

Political representation must, in contrast, be built on competition between 
parties. According to Weber, in the Germany of his time party competition increasingly governed the decision-making not only of municipal assemblies, but also of cooperative bodies, health service boards and so on. Nowadays, in an open and constantly changing market economy, no natural division of occupations or trades is possible. For Weber, party struggle was the appropriate political form for every type of electoral contest. "Wherever one finds rule by means of ballot and elections, the political parties as such are already predisposed to become the bearers of the struggle." ${ }^{\prime x x}$

In a regime of estates neither a debate before the voters (Agitation) nor a decision by vote makes sense. Modern elections are characterized by a competition between 'voluntaristic' parties, based on the free recruitment of supporters: "Political parties in the modern state are organizations which have as their starting point the (legally) free recruitment of supporters, while their goal is to determine policy through the number of their supporters. The ultima ratio of modern party politics is voting or the ballot slip." ${ }^{\prime x x x i}$ The struggle in Parliament and in electoral campaigns is based on numerical strength. Reasons and arguments as well as compromises are important, but the final decision is based on the number of votes.

The vote by ballot (Stimmzettel) is the most important qualification of the modern Parliament and its mode of election. The competition between parties as voluntary organizations regulate the general election and parliamentary voting: their contingency is no hazard or random phenomenon, but an expression of party strength. In Parliament contingency arises from agenda-setting and debate on motions. The agenda-setting itself could perhaps be understood also as a preventive vote, by which the topics of debate are selected. The debates with their aim of persuading the adversary are focused on an estimation of the relative strengths of the parties, and the previous elections and parliamentary votes serve as a background for determining which questions provide a Spielraum for change and in which ones further agitation would be vain and fruitless.

Compromises in Parliament are possible and frequently desirable, but these are conducted against the background of counting of the votes. "This means that, when compromises are reached, it is under pressure from the fact that, if no compromise 
is reached, the subsequent election or ballot may produce a result that is more or less undesirable for all concerned. There is no getting away from the fact that a real or an approximate counting of votes is an integral and essential element both of modern electoral contests and of the conduct of business in parliament."'xxxii In electoral campaigns the diplomatic instruments - threats of war, breaks in diplomatic relations and so on - or their analogs in labor markets - e.g. strikes and boycotts - do not make sense. To boycott an election or a vote in Parliament might be imaginable in extreme cases, for example, one in which fair procedures have been conspicuously violated.

In short, the party competition helps to reduce the contingency of elections to a limited number of realistic alternatives. This holds true independently of whether the competition is between individual candidates in single-member constituencies, or between closed party lists or whether there is a second-level competition between candidates within a party in an electoral district. The art of contingency and the strategic role that parties play in regulating it are different in these three basic cases, but the competition of candidates for the votes of the electorate is common to all of them.

Election day constitutes a deadline for the political time of campaigns. For incumbent parliamentarians it serves as a time-frame, before the end of which it must decide upon the questions on its agenda. If a prime minister or a president has the power to dissolve the parliament, the danger of a sudden interruption of the parliamentary debates before the elections could be understood as more immanent threat than in a fixed-term electoral system.xxxii

The political significance of electoral decisions

The point of general elections with universal suffrage is that, although for individual citizens the casting of votes is highly important, voters remain practically powerless in the face of the contingent results. One vote hardly ever is decisive in broader electorates, and voters misunderstand electoral politics when they complaint that their vote does not count. Of course, politically literate voters might, for example, 
refrain from voting for splinter groupings that have no chance of getting their candidates elected.

However, the electoral decisions may be judged in terms of their political significance for the voter. John Stuart Mill recommended that the voter "give his vote, to the best of his judgment, exactly as he would be bound to do if he were the sole voter, and the election depended upon him alone". xxiv Even if it is pretty clear that your vote does not make a difference in the final outcome, you should vote as if it would; this is the point of Mill's thought experiment.

Jean-Paul Sartre, in his planned Cornell lectures of 1965, cancelled due to his opposition to U.S. policy in Vietnam, made another thought experiment to explain individual electoral choices. His point was that voters do not only choose between the candidates, but by this very choice they also choose their own political image or self-identity. Discussing the primaries of the U.S. Democratic Party between John F. Kennedy and Hubert Humphrey 1960 in West Virginia, the self-choice for Sartre explained why the Catholic Kennedy won over the Protestant Humphrey in a state dominated by Protestants. Every election offers a chance to dissolve one's past prejudices and to recast individual political identity and judgment. The West Virginia Democrats chose Kennedy in order to show that they were tolerant, not bound by their past prejudices. ${ }^{\mathrm{xxx}}$ Sartre's point holds mutatis mutandis for parliamentary elections, although strategic voting is equally legitimate: is it better to choose an excellent candidate with no chances than a mediocre one among those who do have chances?

This corresponds to Weber's view that in parliamentary elections the individual considers herself just as a Staatsbürger. In other words, the citizens can see the elections as an extraordinary occasion to act, in Weber's words, as an "occasional politician" (Gelegenheitspolitiker). Voting is the first activity that Weber mentions when in Politik als Beruf he characterizes the ideal type of occasional politician, which "we all are", xxxvi in contrast to the professional politician. For the occasional politician the point is not the result of the elections, but the right to vote as a chance to participate in the election of parliamentarians. 
The parliamentary link between the debate and the vote

When Weber sees the number of votes as the ultima ratio of parliamentary debate, he recognizes that the final vote in Parliament cannot be separated from the preceding debate and that the arguments in the debate might at any moment alter the majority. Even if he speaks only of party compromises, he by no means underestimates the significance of the debate. The Parliament's main power for Weber lies in the possibility of controlling the administration. "In all mass states democratization leads to bureaucratic administration, and, without parliamentarization, to pure rule by officials." ${ }^{\prime \prime x x v i i ~}$ In the control of the officialdom parliaments are much more efficient than direct democracy.

Weber sees in the possibility of debating the strengths and the weaknesses of a motion a major opportunity in which parliamentarians can show their competencies: "A member of Parliament can learn to weigh the power of words in a party conflict". xxxviiiThe possibility of parliamentarians to control the knowledge of officials is further developed in Weber's academic pamphlet, Parlament und Regierung im neugeordneten Deutschland. He mentions three rhetorical tools of this control, namely, the cross-examination of officials by parliamentarians, the possibility to conduct on-the-spot examination of the sources of the officials' knowledge, and the forms of scrutiny enabled by parliamentary examination commissions ${ }^{\mathrm{xxxix}}$. This view is closely connected to Weber's reinterpretation of 'objectivity' in terms of a fair debate between opposed points of view, for which the Westminster parliamentary procedure offers the historical model.xl

As quoted in the beginning, Gilbert Campion regards the vote as a stage in the debate in the Westminster parliament. "When a motion is moved (and seconded), the Speaker proposes the Question (in the same terms as the motion), as the subject of debate, and at the conclusion of the debate puts the Question for eliciting the immediate decision of the House."xli In the Westminster-style of parliamentary politics, the vote is part of debate at the same time as it terminates it.

The point of the decision arrives when the time for debate is recognized to be at its limit. Also in Parliament an eternal prolongation of debate would appear as a 
pretext against the recognition that at a certain point it is time to move on and vote. The famous obstruction cases of the nineteenth-century even necessitated procedures such as the clôture in order to vote on terminating the debate xlii Similar timelines can be agreed for the intraparliamentary negotiations between parties.

A Westminster specialty is to connect debate with a vote on a resolution. The time limits for debate were recognized already in the tracts on parliamentary procedure in the sixteenth and seventeenth century. The main measure to guarantee that the members speak 'to the matter' is to connect the debate to a resolution, posing a definite question to which the member must take stand in both the debate and the vote. This is still the case with the latest tract on the Westminster procedure:

The process of debate ... is the main process used for most House business.... The process is essentially simple: a member proposes a motion ... that proposal is repeated by the Speaker in the same form; debate arises, the proposal is put for decision; it is agreed or negatived ... if agreed a resolution (expressing an opinion) or an order (requiring action by the House, or a committee, or individual Members or officers) results. xliii $^{\text {. }}$

An old Westminster rule to prevent a senseless prolongation of debate is that in the plenum members are allowed to speak only once to the item on the agenda. Henry Scobell, a Clerk of the House of Commons, formulated this in his tract from the Cromwellian period:

If the Matter moved do receive a Debate pro \& contra, in that Debate none may speak more than once to the Matter; And after some time spent in the Debate, the Speaker collecting the Sense of the House upon the Debate, is to reduce the same into a Question, which he is to propound, to the end, the House in their Debate afterwards may kept to the Matter of that Question, if the same be approved by the House to contain the substance of the former Debate.xliv

In a strict sense, a debate that includes alteration between replies and counterreplies took place only in committee, including in the Committee of the whole 
House. Later on, the rule partially lost its significance due to the parliamentary time budget, because more effective instruments of delay were invented. Since the nineteenth century, replies have received their place also in the plenum, although on certain conditions, as formulated by Campion:

(a) A right to reply is granted to the mover of a substantive motion ... The rule is relaxed

(b) in the case of a Bill under consideration as amended by a standing committee, in favour of the Member in charge and also of the mover of an amendment in respect to that amendment;

(c) in favour of a Member who complains that his meaning has been misinterpreted by another speaker;

(d) to allow a Member, whose conduct or character has been impugned in the debate, to make a personal declaration;

(e) to allow a Member to raise a point of order;

(f) by indulgence of the House (especially when a reply is desired from a Minister). ${ }^{\mathrm{d} l \mathrm{v}}$

The priority of the debate over the vote is thus recognized in the aim of avoiding a premature vote. The main historical instrument for preventing an overly hasty vote, i.e. one without thorough debate, is adjournment, either of debate or of the House itself. Jeremy Bentham already distinguished three types of adjournments: sine die, in diem and post quam. xlvi Adjournment thus does not mean merely a postponement to give the members more time to think the matter on the agenda; it also interrupts the ongoing debate, allowing members to avoid taking a stand on the item on the agenda if they have not already formed a stand or are insecure about the possible outcome of a sudden vote.

An interesting twentieth-century innovation is the creation of adjournment debates without a vote to serve as an extraordinary occasion for the members to take a stand on questions that are not on the ordinary agenda. Different occasions exist for the opposition, the government and the backbenchers. xlvii This can be seen as another example of the priority of the debate over the vote in the Westminster practice.

Parliamentary politics operates with multiple stages (three readings) and layers (plenum and committees) of debate. Each stage and layer offers an institutionalized 
occasion to evaluate a motion on the agenda from a different perspective in order to

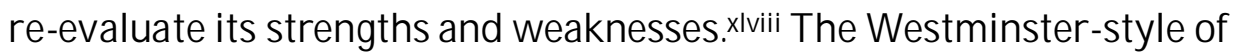
parliamentary debate contains decisions at every stage: they may concern whether to continue the debate at all, whether to accept amendments or whether to adjourn the debate. The final vote on the surviving formulation of a motion is only the last decision, but only it is binding. Parliamentary votes are irrevocable in the short term in so far as a decision on a motion cannot be reversed in the same parliamentary session.

The multiple debates and the subsequent decisions by voting appear much less dramatic than the paradigms of the decisionists, such as declaration of war or a state of emergency. The votes in the first and second reading as well in the committees concern the question, whether or not a motion shall be allowed to move to the next stage of debate. Most motions never reach the final stage, but many members may, in the name of a fair debate, allow a motion to proceed to the next stage, although they firmly intend to vote against it. In contemporary parliaments, with an ever stronger pressure on time, such fairness as to the motions of the opposite side might be more seldom, but it is not the case that all opposition or backbenchers' motions are killed before they are allowed to go to committee.

The parliamentary votes in Westminster are of an either-or character. It is impossible to vote both for and against the same motion or to reject both. Unlike in many other parliaments, no blank vote is allowed, and being absent from the vote leaves the decision to others. Therefore parliamentarians have learnt to choose between evils, often on insufficient grounds.

However, the Westminster practice contains an important modification of this 'absolute' character of the votes, namely the amendment. The political alternatives are formed in terms of amendments that include "Alteration, Addition or Omission," as Henry Scobell put it. xlix Moving an amendment both interrupts the debate on an ongoing motion and originates a new one on the amendment, which also allows those who have already spoken on the original motion to speak again, on the amendment. Originally amendments could not be radically opposed to the sense of the original motion, but in the course of time this restriction has been loosened. 
Accepting an amendment to the original motion is in procedural terms something different than a straightforward rejection, an adjournment sine die or stopping a motion in the early stages of debate! The parliamentary practice of constructing alternatives in terms of amendments can be seen as a both formally and politically important relativization of decisions of the either-or type.

Even more than adjournment, the amendment as a focused alternative to the original motion affirms the priority of debate over the vote. The main point is rather to challenge the strengths of the original motion than present an exact alternative but to insist on the possibility to change the resolution on the basis of the debate.

This priority of debate over vote (decision) holds thus for the Westminster-type of parliamentary politics. If we look at the tracts on the French parliamentary procedure, the tradition is rather the opposite. Vallette and Saint-Marsy during the Orléans monarchy regard the parliament above all as a legislature. For a representative assembly making laws is the aim of parliamentary work, ${ }^{\text {li }}$ and the role of debate is, although necessary clearly subordinated to this: They have no other value than gaining power. lii

Also other features in the French parliamentary procédure tend to give the impression that the debates themselves are not, unlike in Westminster, the main focus of politics. This is the case for example in the replacement of the tacit rejection by means of an adjournment sine die by an explicit rejection, when Poudra and Pierre write in their authoritative tract from $1878^{\text {liiii }}$. Even in the Third Republique, praised rightly by Roussellier as parlement del'éloquence $e^{\text {liv }}$, the debate remained subordinated to vote, as clearly manifested in the frequent falls of government as the major manifestation of the powers of the Assemblée nationale.

The search for one big decision

However, there exist also important either-or decisions in the Westminster Parliament. Their paradigm is the vote of no confidence in the government, initiated by Sandys's motion in 1741 on the basis of pure political expediency. .v $^{\text {T. }}$ The question of confidence in the government is also preceded by a single debate in the plenum, 
which is concludes in a vote concerning dismissal of the government. In this vote policy questions or the government's style of acting politically are subordinate to the chance of dismissing or maintaining the government. Whereas debates and decisions on substantial motions are, in rhetorical terms, of the deliberative genre, the vote on the fate on the government is rather a matter of epideictic rhetoric, which increases the pressure on backbenchers to show party loyalty.

It has been the interests of government to focus parliamentary politics on the either-or decisions between government and opposition. The stable majorities created by election results and the governmental aims to obtain a quasimonopoly of parliamentary initiative have since the nineteenth century contributed to a tendency towards the presidentialization of parliamentary government, resulting in the focus on such either-or decisions. lvi There are, however, good grounds to contest this tendency at Westminster. The multistage and multilayer procedure for debates matters, and the official recognition of the independence and powers of the backbenchers, lvii has limited both governmentalization and presidentialization. Recent reforms have again increased the powers of backbenchers at the expense of party whips. lviii

Another way to combine parliamentary government with a linear up-or-down style of decision-making has involved the electoral majority of the government. In the electoralist perspective, parliamentary politics appears to be restricted to the question of realizing or not realizing the electoral program of the majority parties, against which, however, parliamentary procedure and debate serve as constraints. In an electoralist view the Parliament itself appears as a mere rubber stamp of registration and ratification. Such electoralization is as radical as presidentialization in devaluating parliamentary powers.

The decisive argument against this view is, however, why then keep parliaments with a broad agenda and full-time members at all? Why not replace it with a cheaper, more efficient system, with rotating loyal government supporters enjoying the parliamentary rituals and ceremonies and voting always for the government's case?

Indeed, this is not a new idea. Joseph Cowen, a Radical MP for Newcastle, as early 
as the 1882 debate on the Gladstone government's procedural reform, presented a thought experiment. He was engaged in a polemic against the famous Birmingham Caucus of the Liberals, formed by Joseph Chamberlain. The idea of the Caucus was to subordinate Parliament to parties and elections. lix Cowen asks why an institution as large and costly as the House of Commons should be maintained at all, if it has been reduced to a registry office.

\begin{abstract}
If we are merely to vote as we are told - which is the motto of the Caucus - why are we sent here? It is a great waste of power, of health, of time, and of temper. Instead of 600, 60, or, indeed, 6 would suffice. All that is wanted is a body of experts to whom the decisions taken in the different constituencies might be sent. They might be tabulated, and formulated, and summarized - handed first to a draftsman to embody in Bills, and then to an Executive to put in operation. The Prime Minister desires to lessen the amount of speaking. This is an easy plan of doing it. The work of legislation might be greatly simplified by such a course of procedure. Government shrinks from such a result; but it is the logical, inevitable, and irresistible outcome of their course of action. ${ }^{\text {. }}$
\end{abstract}

Even if, for example, De Gaulle radically reduced the powers of the Assemblée Nationale in the constitution of the Fifth Republic, he still recognized the importance of the opposition and the forms of thorough parliamentary procedure and debate. ${ }^{\mathrm{kx}}$ From populists of a different variety we hear now and then proposals to reduce the parliament's agenda, to shorten its sitting time, to reduce the number of members or to get rid of full-time MPs with their monthly salaries and professional staff. With Cowen I don't think such proposals to devaluate parliaments have any real chance.

While post-war political science has treated parliaments mainly as arenas for parties and government vs. opposition struggles, an increasing scholarly interest in parliaments as parliaments has risen anew in the recent years. ${ }^{\text {lxi }}$ The core idea is that Parliament as a deliberative assembly also incarnates a distinct parliamentary style of thinking politically based on pro et contra debate. It sees, as I quoted Campion, decision as an inherent part of multistage and multilayer parliamentary debate. We could also move to the opposite direction and include voting in elections as a part of parliamentary debate, marking election day as the time when 
membership in Parliament is extended to all voters. ${ }^{\text {xiii }}$

\section{Dedramatization of decisions}

The democratic decisionism of Michael Th. Greven deals with situations in which the decisions are based on the confrontation of a plurality of opposed views, out of which, through debate and voting, a decision must be reached that is also regarded as legitimate by the opponents. lxivIn sharp contrast to the sovereign dictator paradigm, democratic decisionism requires an extended participation by those who are concerned with the decisions in the debates preceding the concluding decision! lxv $^{2}$

In this paper I have continued Greven's dedramatization of decisions with the focus on parliamentary and electoral votes, their political quality and their significance.lxvi The political role of decisions in parliamentary and democratic politics is based on both the relatively rare decisions of voters in parliamentary elections and the very frequent intraparliamentary decisions of a different type and political significance. Neither type of decision is understandable without preceding parliamentary debates on the questions on the agenda as well as on those of the agenda itself.

For the debater the need to terminate debates with decisions by vote illustrates, above all, that all politics operates with limited times. This is also the main reason for the Westminster practice of connecting debates with resolutions to be voted on.

One of the frequent critiques in the name of making democracy 'more participative' is that the system of holding parliamentary elections only every fourth year or so makes of voting in them a rare event. The Sartrean argument that in elections voters choose also their own political profile, supports the idea of keeping elections rare and emphasises their opposition to the Swiss type semi-plebiscitarian regime with frequent referenda. In fact, the municipal, local, European etc. elections contain opportunities for citizens to vote on the basis of campaign-type rhetoric, which dedramatize the electoral choices and allow more complex political profiles.

A more interesting alternative would consist of offering additional occasions to 
the citizens to engage themselves in parliamentary-type debates-cum-decisions independently of elections. The current tendency goes, in the name of efficiency, towards greater units in local politics and, correspondingly, reduces the number of parliamentary-type assemblies and committee-type boards on the local level. This practice not only tends to increase the 'rule of officialdom' (Weber 1918) but also to weaken the citizens knowledge of parliamentary-style debate-based decisionmaking.

Instead of adding citizen consultations in order to render the bureaucratic decision-making more efficient and legitimate, it is high time to activate the citizens' parliamentary-style debating competences to think questions from opposite perspectives. Here the different practices of using the ancient practices of lottery or a combination of candidature and lottery (klerosis ek prokriton in ancient Greece) could be returned to the agenda, as Hubertus Buchstein for example has proposedluxvii.

My point lies rather in increasing the number of parliamentary-type of occasional politicians, acting besides those of the elected assemblies. Parliamentary experiences in debating-cum-deciding are so important that they should not be left to the monopoly of those who candidate in elections. Such parliament-analogical institutions could both control the everyday practices of bureaucratic rule and understand the dissensual perspectives on the agenda-setting and debates on the strengths and weaknesses of the motions on the agenda in political decision-making.

\section{Reference list}

House of Commons. Debate 20 May 1867, vol. 187 cc779-852. Retrieved 12 June 2016 from http:/ / hansard.millbanksystems.com/ commons/ 1867/ may/ 20/ clauses-3-4progress-may- 17.

- 10 November 1882, BUSINESS OF THE HOUSE-THE NEW RULES OF PROCEDURE-FIRST RULE (PUTTING THE QUESTION), Adjourned debate [Nineteenth night] Retrieved 12 June 2016

Bentham, Jeremy. 1843. "Essay on Political Tactics". In Collected Works of Jeremy Bentham, vol. 2, ed. John Bowring, 298-378. Edinburgh: Tait. Retrieved 21 June 2016 from the Online Library of Liberty: 
http:/ / oll.libertyfund.org/ title/ 1921/ 113915.

Buchstein, Hubertus (2009): Demokratie und Lotterie. Frankfurt/ M.: Campus.

Campion, G.F.M. 1929. An Introduction to the Procedure of the House of Commons. London: Allen \& Co.

Cohen, Gottfried.1861. Die Verfassung und Geschäftsordnung des englischen

Parlaments mit Hinweis auf die Geschäftsordnungen deutscher Kammern.

Hamburg: Perthes-Besser \& Mauke. Retrieved 25 June 2016:

http:/ / tinyurl.com/ o556sjt.

Conrad, Burkhard. 2008. Der Augenblick der Entscheidung. Baden-Baden: Nomos.

Crewe, Emma. 2015. The House of Commons. An Anthropology of the MPs at Work.

London: Bloomsbury.

De Mille, James. 1878. Elements of Rhetoric. New York: Harper \& Brothers. Retrieved

25 June 2016: http:/ / tinyurl.com/ mhps972.

Flaig, Egon. 2013. Die Mehrheitsentscheidung. Paderborn: Schöningh.

Garrigues, Jean, ed. 2007. Histoire du Parlement de 1789 à nos jours. Paris: Colin.

Greven, Michael Th. 1994. Kritische Theorie und historische Politik. Opladen:

Leske+Budrich.

Greven, Michael Th. 1999. Die politische Gesellschaft. Opladen: Leske+Budrich. Greven, Michael Th. 2000. Kontingenz und Decision. Opladen: Leske+Budrich.

Griffith, J.A.G. and Michael Ryle. 2003. Parliament: Functions, Practices and Procedures, $2^{\text {nd }}$ ed. Blackburn, Robert and Andrew Kinnon, eds. London: Sweet $\&$ Maxwell.

Habermas, Jürgen. 1968. Technik und Wissenschaft als 'Ideologie'. Frankfurt/ M: Suhrkamp.

Ihalainen, Pasi, Cornelia Ilie and Kari Palonen, eds. 2016. Parliament and

Parliamentarism: A Comparative History of a European Concept. Oxford:

Berghahn.

Ilie, Cornelia, ed. 2010. European Parliaments under Scrutiny. Amsterdam:

Benjamins.

Jaspers, Karl. 1932 [1973]. Philosophie II. Existenzerhellung. Heidelberg: Springer.

Kurunmäki, Jussi. 2000. "Representation, Nation and Time: The Political Rhetoric of the 1866 Parliamentary Reform in Sweden." Ph.D. dissertation. University of Jyväskylä.

Mill, John Stuart. 1859 [1989]. “On Liberty.” In On Liberty and Other Writings, ed.

Stefan Collini, 1-115. Cambridge: Cambridge UP.

Mill, John Stuart. 1861 [1991]. Considerations on Representative Government.

Buffalo: Prometheus Books.

Palonen, Kari. 2008. The Politics of Limited Times. Baden-Baden: Nomos.

Palonen, Kari. 2010a. "Objektivität" als faires Spiel. Wissenschaft als Politik bei Max Weber. Baden-Baden: Nomos.

Palonen, Kari. 2010b. “The Parliamentarisation of Elections.” Redescriptions 14: 133-156.

Palonen, Kari. 2012. "Parlament und Freiheit. Eine rhetorische Perspektive zur

Kontingenz". In Katrin Toens and Ulrich Willems (eds), Politik und Kontingenz,

99-115. Wiesbaden: Springer VS.

Palonen, Kari. 2014. The Politics of Parliamentary Procedure: The Formation of the 
Westminster Procedure as a Political Ideal Type. Leverkusen: Budrich.

Palonen, Kari. 2016. From Oratory to Debate: Parliamentarisation of Deliberative

Rhetoric in Westminster. Baden-Baden: Nomos.

Pekonen, Onni. 2014. Debating the ABCs of Parliamentary Life: The Learning of

Parliamentary Rules and Practices in the Late Nineteenth-century Finnish Diet

and the Early Eduskunta. Ph.D. dissertation: University of Jyväskylä.

Plessner, Helmuth. 1931. "Macht und menschliche Natur." In Gesammelte Schriften,

135-234. Bd. V. Frankfurt/ M: Suhrkamp.

Poudra, Jules. and Eugène Pierre. 1878. Traité de droit politique, électoral et

parlementaire. Versailles: Cerf: http://tinyurl.com/nvkt9r9

Redlich, Josef. 1905. Recht und Technik des Englischen Parlamentarismus. Leipzig:

Duncker \& Humblot.

Rosanvallon, Pierre. 2015. Le bon gouvernement. Paris: Seuil.

Roussellier, Nicolas.1997. Le parlement d'éloquence. Paris: Presses de Sciences-po.

Sartre, Jean-Paul. 1948. "Qu-est-ce que la littérature?" in Situations II, 55-330. Paris:

Gallimard.

Sartre, Jean-Paul. 1991. “Kennedy and West Virginia”. In Sartre Alive, ed. Ronald Aronson and Adrian van den Hoven, 37-52. Detroit: Wayne State University Press.

Schmitt, Carl. 1919 [1968]. Politische Romantik. Berlin: Duncker \& Humblot.

Schmitt, Carl. 1921 [1978]. Die Diktatur. Duncker \& Humblot.

Schmitt, Carl. 1922 [1979]. Politische Theologie. Berlin: Duncker \& Humblot.

Schmitt, Carl. 1928 [1970]. Verfassungslehre. Berlin: Duncker \& Humblot.

Schulz, Andreas and Andreas Wirsching, eds. 2012. Parlamentarische Kulturen in Europa. Das Parlament als Kommunikationsraum. Düsseldorf: Droste.

Scobell, Henry. 1656. Memorials of the Method and Manner of Proceedings in Parliament in Passing Bills. London: Hills and Fields. EEBO Editions.

Skinner, Quentin. 1996. Reason and Rhetoric in the Philosophy of Hobbes. Cambridge: Cambridge UP.

Turkka, Tapani. 2007. The Origins of Parliamentarism: A Study of Sandys' Motion. Baden-Baden: Nomos.

Vaarakallio, Tuula. 2014. "Re-Activating the Parliament of Eloquence? Sarkozy's Reform of Procedure in the French Assemblée Nationale." In The Politics of Dissensus: Parliament in Debate, ed. Kari Palonen, José María Rosales and Tapani Turkka, 375-98. Santander: University of Cantabria Press and McGraw Hill.

Valette, Philippe. and Benôit Saint-Marsy. 1839. Traité de la confection des lois, ou examen raisonnée des règlements suivis par les assemblées legislatives françaises, compares aux formes parlementaries de l'Angleterre, des États-Unis, de la Bélgique, de l'Espagne, de la Suisse, etc. Paris: Joubert, http://tinyurl.com/zrfkw3o

Weber, Max. 1917 [1988]. "Wahlrecht und Demokratie in Deutschland”. In Max-

Weber-Studienausgabe, I/ 15, ed. Wolfgang J. Mommsen, 155-189.

Tübingen: Mohr.

Weber, Max. 1918 [1988]."Parlament und Regierung im neugeordneten

Deutschland." In Max-Weber-Studienausgabe I/ 15, ed. Wolfgang J. Mommsen, 202-302. Tübingen: Mohr. 
Weber, Max. 1919 [1994]. "Politik als Beruf”. In Max-Weber-Studienausgabe 1/17, ed. Wolfgang Schluchter and Wolfgang J. Mommsen, 35-88. Tübingen: Mohr. Weber, Max. 1922 [1980]. Wirtschaft und Gesellschaft, ed.Johannes Winckelmann. Tübingen: Mohr.

Weber, Max. 1994. Political Writings, ed. Peter Lassman and Ronald Speirs, trans. Speirs. Cambridge: Cambridge University Press.

Wright, Tony. 2012. Doing Politics. London: Biteback.

iSchmitt, Theologie.

ii See e.g. Plessner, Macht, Greven, Kontingenz.

iii Weber 1917.

iv See in more detail Palonen Procedure; Oratory.

v Campion, Introduction, 143.

vi De Mille, Elements, 473.

vii Quoted in Skinner Reason, 300.

viii "ist die Intention eines allgemeinen und ungezwungenen Konsenses

umißverständlich ausgesprochen", Habermas, Technik, 163

ix "In letzter Instanz kann sich das politische Handeln nicht rational begründen, es realisiert vielmehr eine Dezision zwischen konkurrierenden Werteordnungen und Glaubensmächten, die zwingenden Argumenten entraten und einer verbindlichen Diskussion unzugänglich bleiben.” Habermas, Technik 121.

x See Greven, Theorie

xi See Greven, Gesellschaft; Kontingenz.

xii See Jaspers, Philosophie II; Sartre, Littérature

xiii Greven Kontingenz, 54.

xiv See e.g. Skinner, Reason.

xv Mill, Liberty, 20.

xvi House of Commons, 20 May 1867, clauses-3-4.

xvii Schmitt, Romantik, 40.

xviii On Kierkegaard concept of decision, see Conrad, Augenblick.

xix "[E]ine reine, nicht räsonnierende und nicht diskutierende, sich nicht rechtfertigende, also aus dem Nichts geschaffene absolute Entscheidung," (Schmitt Theologie, 83.

xx "Souverän ist, wer über den Ausnahmezustand entscheidet" (Schmitt, Theologie 11, see also Schmitt, Diktatur.

xxi “Das Plebiszit ist keine 'Wahl', sondern erstmalige oder ... erneute Anerkennung eines Prätendenten als persönlich qualifizierten, charismatischen Herrschers." Weber, Wirtschaft, 665.

xxii Schmitt, Verfassungslehre, 83-84, 242-252.

xxiii “Die Akklamation der Beherrschten kann sich aber umgekehrt zu einem regulären 'Wahlverfahren' entwickeln, mit einem durch Regeln normierten 'Wahlrecht', direkten oder indirekten, 'Bezirks'- oder 'Proportionalwahlen', Wahlklassen' und 'Wahlkreisen'."Weber, Wirtschaft, 666.

xxiv "[Z]um Repräsentativsystem ist die Herrscherwahl nur im Okzident allmählich entwickelt worden", Weber, Wirtschaft, 666. 
xxv "Feigheit des Bürgertums vor der Demokratie"

xxvi Weber, Writings, 103. In original: "Dem modernen Staat erst gehört der Begriff des 'Staatsbürgers' an. Und das gleiche Wahlrecht bedeutet zunächst

schlechterdings nichts anderes als: daß an diesem Punkt des sozialen Lebens der einzelne einmal nicht, wie sonst überall, nach seiner Besonderung in beruflichen und familienhaften Stellungen und nach den Verschiedenheiten seiner materiellen oder sozialen Lage in Betracht kommt, sondern eben nur: als Staatsbürger. "Wahlrecht, 170.

xxvii On the majority principle see Flaig, Mehrheitsprinzip.

xxviii Weber, Writings, 102. In original: "Nur als das Kompromiß die rechtliche Grundlage politischen Handelns war, war auch die ständische Berufsgliederung ihrem Wesen nach am Platze." Wahlrecht 169.

xxix See Kurunmäki, Representation, Pekonen, ABC.

xxx Weber, Writings, 94. In original "[D]aß überall, wo Wahlzettel und Agitation herrscht, die politischen Parteien als solche schon jetzt dazu prädisponiert sind, Träger des Kampfes zu werden.” Wahlrecht, 164.

xxxi Weber, Writings. 99. In German."Politische Parteien sind dagegen im modernen Staat Organisationen, welche auf (rechtlich) 'freie' Werbung von Anhängern ausgehen und deren Ziel ist: durch die Zahl ihrer Anhänger die Politik zu bestimmen: die ultima ratio aller modernen Parteipolitik ist der Wahl- oder Stimmzettel." Weber Wahlrecht, 167.

xxxii Weber, Writings, 102. In the original: "[U]nter dem Druck, daß in Ermanglung des Zustandekommens des Kompromisses die dann stattfindende Wahl oder Abstimmung ein vielleicht allen Beteiligten annähernd gleich unerwünschtes Resultat haben werde. Wirkliche und schätzungsweise Stimmenzählung gehört nun einmal zum eingeborenen Wesen des modernen Wahlkampfes sowohl als der parlamentarischen Geschäftsführung." Wahlrecht, 169.

xxxiii See the discussion in Palonen, Times.

xxxiv Mill, Considerations, 208.

xxxv Sartre, Kennedy.

xxxvi Weber, Politik, 41; Writings, 316-7.

xxxvii Weber, Writings , 127. In German: "In jedem Massenstaat führt Demokratie zur bürokratischen Verwaltung, und, ohne Parlamentarisierung, zur reinen

Beamtenherrschaft", Wahlrecht, 187. xxxviii Weber, Writings, 127. In German: "[D]aß ... ein Parlamentarier im Kampf der

Parteien zu lernen vermag, die Tragweite des Wortes zu wägen", Wahlrecht, 187. xxxix Weber Parlament, esp. 235-237, Writings,177-180.

xl See the discussion in Palonen, "Objektivität".

xli Campion, Introduction, 145.

xlii See Redlich, Recht.

xliii Griffith and Ryle, Parliament, 86.

xliv Scobell, Memorials, 22.

xlv Campion Introduction, 167.

xlvi Bentham Tactics, § XII. 
xlvii See Campion Introduction, 91-92; Griffith and Ryle Parliament, 376, 379.

xlviii For this idea see Cohen, Verfassung

xlix Scobell, Memorials, 22-23.

1 See Palonen, Procedure.

li “La loi est encore le but final de l'œuvre parlementaire," Valette and Saint-Marsy,

Traité, 4.

lii “Ces débats nous paraissent accessoires en ce sens qu'ils ne constituent jamais que des moyens pour arriver à un but : la conquête du pouvoir.", ibid.

liii "C'est par la voie du rejet formel et non par la voie indirecte du adjournement que la Chambre écarte un projet dont elle ne veut pas," Poudra and Pierre, Traité, 658.

liv Roussellier, Parlement.

lv See Turkka, Origins.

lvi On this thesis see Rosanvallon, Gouvernement.

lvii This aspect was already emphasised by the Whittaker Committee of 1913/ 14, discussed in Palonen, Oratory.

lviii See Wright, Politics, Crewe, House.

lix On the Caucus see Weber, Politik, 63-65.

ix House of Commons, 10 November 1882, 1217

lxi On the procedural reform to strengthen the parliament under Sarkozy see Vaarakallio, Parliament.

lxii See Garrigues, Histoire; Ilie ed. Parliament; Schulz und Wirsching, Parlament; Ihalainen, Ilie and Palonen eds. Parliament.

lxiii On this thought experiment see Palonen, Elections.

lxiv Greven, Kontingenz, 57.

lxv Greven, Kontingenz, 62.

lxvi See also my discussion on electoral and parliamentary contingency in Palonen, Parlament

lxvii For the contemporary debates on lottery see e.g. Buchstein, Demokratie. 